\title{
David Clowes, The Economic and Security Challenges Facing NATO’s EU Member States, Kraków 2018, pp. 152
}

W ithin 30 years after the end of the Cold War and 20 after first NATO enlargement on former Soviet Bloc countries, the alliance evolved into a defensive pact without explicitly specified opponent. In its current nature it is widely perceived as a pillar and main component of European defense system, protecting its members from both traditional and unconventional threats and challenges. The expansion of Islamic terrorism, aggressive foreign policy of the Russian Federation, resulting in conflicts in Georgia and Ukraine, and two massive crises - economic from 2008 and migration from 2015, have largely determined the shift in the perception of threats in the EU Member States. However, despite progressing integration of the former Eastern Bloc countries with the West within both the EU and NATO structures, due to the differences in economic potential, historical experience and geographical location, both the perception of threats and security policy priorities as well as their capabilities differ in the Old and the New Europe. This divergence is the main subject of David Clowes' work The Economic and Security Challenges Facing NATO's EU Member States.

The work serves two purposes. Its main goal is to present how NATO's European members perceive major, both economic and political, challenges to European security of recent years - migration crisis, war in Ukraine, economic inequality, and the European Union's dependence on imports of Russian resources (mainly gas). Additionally, it shows their response to these threats by presenting changes in their defense spending and their military and economic power fluctuation over the years 2000-2014 in the form of a powermetric report. The main hypothesis of the work concerns the need to transform the NATO based European security system so that it would be able to meet modern challenges. The author argues that to do this, in order to level the disproportion between the old and the new European Union, the transfer of power to NATO's eastern flank is necessary. The author conducted his research mainly on the basis of quantitative 
approach, using two powermetric models of his own design, created by transformation of the Cline's formula and using statistical analysis based on the data collected by, i.a., SIPRI and Eurostat. The author adopted the annual expenditure of the surveyed states in areas of interest to him as the most important indicator of both power and priorities in national security policy.

The substantive part of David Clowes' work consists of an introduction presenting a research problem, six chapters and a summary presenting the conclusions. The work structure is logical, the following chapters are closely related and build on the previous ones. The first chapter focuses on global trends in changes in defense spending in 2000-2014. The author points to the connection between the increase in stability in post-Cold War Europe and the relative decrease in its defense spending - which in turn is growing simultaneously in both Russia and China. The second chapter serves the purpose of providing theoretical background and presents selected models for calculating the state power. The author pays special attention to one formula developed by Cline, which he chooses as a basis on which he constructed his own research tools, and presents the results of state power calculation utilizing it. The author also subjects the Cline model to critical analysis, rejecting its non-quantifiable components (strategic goal and national will) in order to obtain more precise measurement. The author presents the results of his own models-based research in the third and fourth chapters. In the third chapter, using $2 \times 3$ factors formula, he compares the indicators of the leading global powers - the United States, the European Union, the Russian Federation, the People's Repub- lic of China, and the Republic of India, and in a more accurate approach, presents the estimated power of the twenty strongest countries. The fourth chapter presents the results of measurements carried out on a European scale, comparing them with the global range of the EU's six strongest countries' power (Great Britain, Germany, France, Italy, Spain, and the Netherlands), with the use of author's second, $3 \times 3$ factor model. The penultimate chapter deals with the aforementioned disproportion in both military strength and defence expenditure between Western and Eastern Europe. Author's research shows noticeable growth in the New Europe defence spending after annexation of Crimea, with both rising support for European joint army and more countries promising to meet NATO's requirement of $2 \%$ of GDP spending on the defence in the near future. The last chapter presents the analysis of threat perception within the EU Member States and changes in their defence strategies. Author also offers an insight into possible course of action that states might take in the following years, basing his statements on their evolving strategies. The book also provides the reader with a significant amount of tables, charts and maps, placed both within the text of the chapters and in the annex.

The temporal range of work is rather wide. In his analysis, the author referred to state's expenditure data for the years 2001-2014, although in matters of perception of threats he also used data from up to 2016. It is also noteworthy that the author treated the issue of perception of threats on two levels - forming his claims based on both public opinion surveys and government spending analysis. In addition, as mentioned earlier, the author does not focus only on the regional scale, and he compares the EU's NATO members' 
power measurement results with both the indicators of non-European NATO members and, on a global scale, with leading powers. Thanks to such an extension of perspective, author's research indicates a relative decline in the EU's power over the period of time, in contrast to accelerated growth of power and the rising importance of Russia, China, and India. The author also mentions the recurring issue of the creation of joint European armed forces, but he devotes relatively little attention to it. The presented catalogue of challenges facing European NATO members is wide, and covers both political and social issues to the extent that they determine the economic and military security of states.

However, the selection of factors taken into account in the author's model might be considered controversial. According to the $3 \times 2$ formula used in the research, the total power of the state is determined by critical mass (population and territory), economic potential (GDP index and foreign investment), and military strength (expenditure on armaments and the export of military equipment). Thus, the author completely omits the component of broadly understood "soft power", which, as he claims, is in practice impossible to precisely estimate. However, it is one of the most important expansion areas for the EU countries, both at the level of declarations and operations. Equally controversial is the fact that in the proposed model, military power is determined only by expenditure on armaments and equipment exports. The first factor is always relative and is not a direct indicator of the training level, number of active personnel, quality of equipment and general efficiency of the army. The second one is purely economic and only indicates the level of development of the domestic defense industry, which does not necessarily translate into the strength of state's own armed forces. For example, placing the Netherlands at the position of the sixth military force of the European Union is mainly caused by the very high amount of arms and military equipment exports. Military power analyses carried out with this model are therefore quite inexact and can indicate more the military potential than the real strength of the army. For comparison, the indicator of military power developed by the Global Firepower Ranking takes into account a number of different factors, presenting the military strength of countries more precisely. It is even more noticeable, because the work also contains a compilation of the number of personnel and military equipment in the countries of Europe and the Caucasus developed by the author, so the use of this data in the model would remedy this controversy.

One can also have some reservations about a degree of reductionism visible in the work. Analyzing the military and economic power of the European Union, the author treats it as one entity, summing up the values of indicators of all the Member States. This approach does not accurately reflect reality, what can be best explained on the ground of the serious problems encountered by those who advocate for the concept of creating joint European armed forces for over twenty years. Additionally, the results of analysis of the perception of citizens about threats and EU's operational capabilities are presented variously. The presentation of citizens' opinion on stability and main threats is broken down by country, while the opinion on the most important assets of the Union is presented in an absolute way - as the answers most often chosen by all the EU citizens. Thus, the demographic disproportion between 
the countries of the "Old" and the "New" Union is not taken under consideration. Although it is worth noting that the author acknowledges in his research that NATO can be perceived as a potential threat to the European security in the perception of the Eastern European countries and an indication of its exceptionally low support in Greece and Bulgaria. Thanks to this extension of perspective, the internal division in the perception of threats by the EU Member States is much more visible and seems larger than it would appear if one assumed that NATO is widely considered an indispensable element of the European security system.

The book has an extensive bibliography. The author in his research used, i.a., reports made by institutions such as SIPRI or Eurostat. He also utilized official plans, strategies and reports issued by Member States organs. In bibliography reader can also find theoretical works, both in the field of the mentioned powermetric and the theory of international relations. The diversity of sources is noteworthy - there are works issued in English, Polish, Ger- man, or Turkish language. A significant part of the sources, however, is of journalistic nature, as they are press articles published on the Internet.

The work has a special scientific value in the context of current events. Both the idea to create the European Armed Forces that recently has been re-embraced and funded by the European Defense Fund launched in 2017, and the strengthening of the NATO's Eastern Flank by American troops indicates the return of the military defense as the major priority of the European countries' security strategy. The multi-level threat perception analysis carried out by the author clearly indicates a still deep divergence between the Old and the New Europe. In addition, the powermetric research, although a bit inexact, as aforementioned, certainly shows the potential assets and resources that EU's NATO members may have at their disposal to deal with identified threats. Therefor the work is a valuable source for potential research that deals with assessing the effectiveness of potential solutions that EU countries could take. 